\title{
Implementasi Kebijakan Pelaksanaan Program Pengendalian Tuberculosis Dilihat dari Aspek Pembiayaan Menurut Stakeholder Kunci
}

\author{
Implementation of Policies for the Implementation of the Tuberculosis Control Program Seen \\ from the Financing Aspect by Key Stakeholders
}

\author{
Erwin Purwaningsih ${ }^{1}$ \\ Departemen Administrasi Rumah Sakit, Sekolah Tinggi Ilmu Kesehatan \\ Mutiara Mahakam \\ Jl Ery Suparjan, No. 49A RT 12 Sempaja Selatan, Samarinda, Kalimantan Timur \\ Email: 1 ri_wien18@yahoo.com
}

\begin{abstract}
ABSTRAK
Tingginya angka kasus tuberkulosis yang ada di Samarinda, membuatnya menjadi salah satu isu kesehatan yang menjadi pokok pada program kesehatan kota. Pembahasan mengenai faktor penyebab, program penyelesaian, hingga sumber daya menjadi hal yang wajib dibahas pada setiap agenda kesehatan yang dijalankan. Aspek pembiayaan yang belum maksimal menjadi fokus pada penelitian kali ini, karena merupakan salah satu faktor kunci keberhasilan program TB di kota Samarinda. Desain Studi: Deskriptif kualitatif dengan desain studi kasus. Metode: Subjek terpilih berjumlah 18 orang berasal dari pihak legislatif, eksekutif, penyedia pelayanan kesehatan dan lintas sektoral di wilayah kota Samarinda. Subjek penelitian dipilih melalui teknik purposive sampling. Penelitian dilakukan dengan melakukan wawancara yang direkam menggunakan alat perekam, kemudian dilakukan pengumpulan data sekunder dari institusi subjek penelitian yang bersangkutan. Hasil: Terdapat beberapa pilihan kebijakan pada pembiayaan program TB di Kota Samarinda. Diantaranya terdapat inisiatif untuk penyusunan peraturan daerah mengenai TB-HIV. Termasuk didalamnya akan memuat kebijakan mengenai pembentukan forum Corporate Social Responsibility (CSR) yang menampung aspirasi dan penyaluran bantuan (materi atau pendanaan) dari pihak perusahaan/badan usaha yang terdapat di Kota Samarinda. Aspek pelaksanaan kegiatan lintas sektoral juga menjadi salah satu fokus dan perhatian pada penyusunan peraturan daerah ini.Kesimpulan: Adanya payung hukum berupa peraturan perda (Perda) merupakan hal krusial dalam penyelesaian kasus TB yang ada di kota Samarinda. Hal tersebut, membuat setidaknya penanganan di lapangan bisa berjalan maksimal, baik dari segi pendampingan maupun anggaran.
\end{abstract}

Kata Kunci: Kebijakan Pembiayaan, Program TB, Stakeholder Kunci 


\begin{abstract}
Due to the obvious large number of tuberculosis cases in Samarinda, it is one of the city's most common health problems. Every health agenda that is carried out must include discussions on the causing issues, remedy initiatives, and resources. The focus of this study is on the component of financing that has not been fully utilized, as it is one of the most important variables in the success of the TB program in Samarinda. The study was designed as a qualitative descriptive case study. Methods: The participants were 18 people from the city of Samarinda's legislative, executive, health-care providers, and cross-sectors. Purposive sampling was used to choose research participants. The research was carried out by conducting interviews that were tape recorded, and then secondary data was collected from the research subject institution concerned. Results: In Samarinda City, there are numerous policy choices for funding the TB program. Initiatives for the formulation of local regulations relating TB-HIV are among them. This includes laws on the creation of a Corporate Social Responsibility (CSR) forum to accommodate goals and the distribution of help (materials or funding) from companies/business organizations in Samarinda. One of the focuses and concerns in the preparation of this regional rule is the element of executing cross-sectoral activities. Conclusion: In the city of Samarinda, the existence of a legal umbrella in the form of a regional regulation (Perda) is critical in settling TB cases. At the very least, this allows for optimal field management, both in terms of help and budget.
\end{abstract}

Keywords : Financing policy, TB program, Key stakeholder

\title{
PENDAHULUAN
}

Tuberkulosis merupakan penyakit yang menjadi perhatian global (WHO, 2016). Tuberkulosis (TB) adalah salah satu ancaman kesehatan masyarakat yang utama. Meskipun kecenderungan menurun dalam insiden TB, prevalensi dan mortalitas telah diamati selama dekade terakhir, eliminasi penyakit di tingkat global masih jauh dari jangkauan, dan investasi sumber daya besar masih diperlukan(Sulis, Roggi, Matteelli, \& Raviglione, 2014).

Kebijakan-kebijakan kesehatan dibuat oleh pemerintah dan swasta. Kebijakan merupakan produk pemerintah, walaupun pelayanan kesehatan cenderung dilakukan secara swasta, dikontrakkan atau melalui suatu kemitraan, kebijakannya disiapkan oleh pemerintah di mana keputusannya mempertimbangkan juga aspek politik (Buse, May \& Walt, 2005). Dalam era desentralisasi, pembiayaan program kesehatan termasuk pengendalian TB sangat bergantung pada alokasi dari pemerintah pusat dan daerah. Alokasi APBD untuk pengendalian TB secara umum rendah dikarenakan masih tingginya ketergantungan terhadap pendanaan dari donor internasional dan banyaknya masalah kesehatan masyarakat lainnya yang juga perlu didanai. 
Rendahnya komitmen politis untuk pengendalian TB merupakan ancaman bagi kesinambungan program pengendalian TB. Program pengendalian TB nasional semakin perlu penguatan kapasitas untuk melakukan advokasi dalam meningkatkan pembiayaan dari pusat maupun daerah baik untuk pembiayaan program maupun biaya operasional lainnya sesuai kebutuhan daerah. Saat ini struktur pembiayaan yang tersedia lebih banyak terpusat kepada aspek kuratif sedangkan pembiayaan untuk aspek promotif, preventif dan rehabilitatif masih sangat kecil (Kemenkes RI, 2014).

Tujuan penelitian ini adalah melakukan analisis terhadap regulasi dan bentuk kebijakan pada aspek pembiayaan program TB dilihat dari daya dan upaya yang dilakukan oleh stakeholder kunci Selain itu, dapat digunakan sebagai masukan yang sangat diperlukan untuk melakukan evaluasi ekonomi, aspek pelaksanaan program, pengujian dan program pencegahan TB. Akhirnya, hasil dari penelitian ini akan memberikan penjelasan tentang penggunaan tes TB dan tolok ukur pengeluaran medis yang dapat berguna untuk menilai trend.

\section{METODE}

Penelitian ini mengacu pada data penelitian yang lebih besar yang dikumpulkan untuk tesis. Penelitian ini adalah investigasi konteks kebijakan para stakeholder/pihak yang sangat berperan untuk pengendalian TB. Dimensi lain dari penelitian ini termasuk kemitraan publik swasta, komitmen politik, serta hambatan dan prospek untuk pengendalian TB di Samarinda. Data dikumpulkan antara Januari dan Februari 2018. Makalah ini didasarkan pada sampel 18 responden yang dipilih dari institusi pemerintah terkait dengan alokasi dana kesehatan yaitu institusi kesehatan dan non kesehatan. Wawancara lebih lanjut dihentikan ketika kami mencapai kejenuhan.

\section{HASIL}

Hasil penelitian temuan disajikan sesuai dengan tiga elemen konseptual di inti studi eksplorasi yaitu: peraturan pusat, peraturan daerah dan bentuk regulasi. Hasilnya diilustrasikan menggunakan kutipan langsung dari responden: 


\section{Regulasi}

\section{Regulasi Pusat}

Kebijakan terkait peraturan mengenai TB yang berasal dari pusat terkait SPM yaitu Permenkes no 741/Menkes/Per/VII/2008 dan yang terbaru Permenkes no 43 tahun 2016. Selanjutnya terkait upaya penanggulangan TB yaitu Permenkes no 67 tahun 2016. Sesuai kutipan wawancara berikut:

“......program tetep mengikut pusat karena itu program nasional....” (R5/Dinkes)

Regulasi dari pusat yang mengatur pemenuhan SDM untuk pemberi pelayanan kesehatan dilakukan berdasarkan perencanaan yang disesuaikan dengan Permenkes No 14 tahun 2014 (ralat dari pernyataan responden: Kemenkes No.14 tahun 2010), sebagaimana pernyataan responden berikut ini:

"Perencanaan kebutuhan-kebutuhan kebijakan pemenuhan program Tb itu ...mengacu pada Kemenkes no.14 tahun 2010....." (R4/Dinkes)

Beberapa peraturan dari pusat yang diadopsi di daerah diantaranya mengatur tentang target dan sasaran program penanggulangan TB dengan beberapa peraturan Permenkes. Selanjutnya peraturan mengenai pemenuhan SDM yang diatur oleh pusat juga diadopsi oleh daerah melalui Permenkes.

\section{Regulasi Daerah}

Kesehatan menjadi salah satu pilar pembangunan nasional, sama halnya di kota Samarinda. Kesehatan termasuk dalam visi misi Walikota Samarinda yang tertuang dalam RPJMD, keterangan ini sesuai dengan kutipan wawancara dengan informan sebagai berikut:

"Iyah, di kota Samarinda ini...visi misi dari pak walikotanya maupun program dari RPJMD dari Kalimantan Timur sampe kota Samarinda itu memang prioritas utama.....” (R1/DPRD) 
Sebagai kota dari seluruh kabupaten/kota yang memiliki jumlah kasus tertinggi, ternyata Samarinda belum memiliki peraturan daerah (perda walikota) dalam hal penanganan TB di kota Samarinda. Pihak DPRD dan dinas kesehatan kota Samarinda sepakat bahwa terdapat rencana untuk penyusunan Perda tentang pengendalian penyakit TB dan HIV. Antara lain seperti pernyataan responden berikut ini:

“.......kebijakannya ini yang untuk untuk tahun ke depan kita akan membuat Perda tentang pengendalian penyakit TB dan HIV.....” (R5/Dinkes)

Terdapat kebijakan telah diatur dan disusun dalam renstra dinas yang kemudian akan dimasukkan ke dalam Rencana Kerja Perangkat Daerah (RKPD) dan Rencana Kerja Anggaran (RKA), hal tersebut dapat dilihat dari pernyataan informan berikut ini:

“......di renstra, renstra dinas kesehatan kota samarinda dan itu di renstra itu kita RKPD dan di RKA Puskesmas...di RKA dinas kesehatan dan puskesmas......” (R3/Dinkes)

Kebijakan pembiayaan saat ini masih dibantu oleh pihak global fund. Dahulu biaya kesehatan masyarakat kota Samarinda dibiayai melalui Jamkesda, namun beralih ke BPJS Kesehatan sesuai dengan peraturan baru yang berlaku sesuai dengan kutipan wawancara informan berikut ini:

“.....pembiayaan TB selama ini masih kita dibantu oleh pihak global fund, itu free....sekarang kan diarahkan memang kan ke BPJS, cuma memang yang namanya untuk penyakit TB itu sudah ditanggung oleh pemerintah BPJS, biarpun pengobatannya sifatnya lama....." (R7/Dinkes)

Beberapa poin kebijakan yang menjadi dasar pengendalian TB di kota Samarinda antara lain kebijakan yang berada di level pemerintah daerah dan dinas kesehatan Kota Samarinda. Kebijakan di level Pemda antara lain kesehatan menjadi salah satu visi dan misi dari walikota dan adanya rencana penyusunan Perda TB-HIV kota Samarinda. Kebijakan secara teknis diatur di dinas kesehatan kota Samarinda yang terdapat pada renstra dinas. Pada aspek pembiayaan Dinkes Samarinda memperoleh dana program melalui bantuan GF. 


\section{PEMBAHASAN}

Di Indonesia, dikenal adanya dokumen strategi nasional pengendalian TB. Dokumen stranas TB tahun 2015-2019 disusun berdasarkan capaian strategi nasional tahun lalu dan disesuaikan dengan perubahan-perubahan global maupun kebijakan nasional terkini, yang memungkinkan pembagian tanggung jawab pada tingkat sub-nasional serta memperkuat pemerintah kota/kabupaten. Program nasional TB juga perlu memberikan dukungan untuk memperbaiki koordinasi dan monitoring dan evaluasi di 18 provinsi (Kemenkes RI, 2015). Hal ini menunjukkan bahwa pentingnya kedudukan dari kebijakan pengendalian TB dari level pusat hingga level daerah (level provinsi serta kabupaten/kota). Berdasarkan hasil penelitian, diketahui bahwa untuk level kebijakan daerah, Kota Samarinda belum memiliki kebijakan berupa peraturan daerah yang mengatur mengenai program pengendalian TB. Sesuai rencana, peraturan daerah ini akan disusun pada tahun 2019. Di dalam peraturan daerah ini nantinya akan mengatur berbagai kompenen yang menentukan keberhasilan program pengendalian TB dan HIV. Salah satu aspek yang diatur juga memuat pengaturan mengenai CSR. CSR diharapkan dapat menjadi salah satu pembiayaan TB selain dari APBN, APBD, Global Fund dan pendanaan BPJS yang merupakan sumber penggunaan dana terbesar di Samarinda.

Konsep CSR telah berkembang pesat dalam beberapa dekade terakhir, menarik perhatian dari pelanggan, pemangku kepentingan, komunitas penelitian, pemerintah, dan perusahaan (European Commission, 2001). Sebagai sistem pengaturan diri pribadi, CSR harus bekerja dalam satu set batasan yang berbeda dari sistem peraturan publik(Sheehy, 2017). Undang-undang Indonesia tahun 2007 No. 40 muncul sebagai undang-undang CSR wajib, 1 tantangan pelaksanaan untuk menghadapinya adalah lebih mudah dikatakan daripada dilakukan (Waagstein; Patricia Rinwigat, 2011).

Selama implementasi Perda TB HIV Initiative tentang CSR, para pemangku kepentingan menghadapi beberapa tantangan yang membutuhkan perubahan untuk diterapkan pada kegiatan pelaksanaan CSR. Ini biasa dalam intervensi yang rumit untuk memastikan bahwa kebutuhan berbagai pemangku kepentingan terpenuhi(Rabin, Brownson, Haire-Joshu, Kreuter, \& Weaver, 2008). Keterlambatan pembuatan peraturan daerah untuk membentuk forum CSR, membuat perencanaan belum dapat terealisasi. Sebagai contoh, terbukti merupakan tantangan penting sebagaimana yang dirasakan oleh peraturan daerah ini mempengaruhi kemampuan mereka untuk mencapai sumber pembiayaan kesehatan tertentu. Pendataan badan-badan baik milik pemerintah 
dan swasta wajib dilakukan untuk dapat melaksanakan kebijakan CSR. Sistem yang sangat terpusat, yang melemahkan otoritas lokal, menantang intervensi pemerintah Samarinda karena struktur pembiayaan mereka harus bergantung pada kemampuan untuk memobilisasi dan mengelola sumber daya di tingkat lokal daripada di tingkat pusat(Ireland, Paul, \& Dujardin, 2011).

Perlu diingat bahwa program pengendalian TB tidak akan berhasil jika hanya melibatkan peran institusi kesehatan walaupun dengan pembiayaan yang besar. Dibutuhkan the outer setting comprises an organization's economic, political, and social context (Damschroder, L.J., D.C. Aron, R.E. Keith, S.R. Kirsh \& Lowery, 2009). Kerjasama dan peran dari institusi-institusi terkait lainnya juga dibutuhkan agar pencapaian target dapat terpenuhi. Pemerintah melalui Kementerian RI menargetkan Indonesia tidak memiliki kasus tuberkulosis (TB) baru pada tahun 2035. Zero TB 2035 tidak akan berhasil jika hanya sektor kesehatan saja yang bekerja. Penanganan yang komprehensif dan lintas sektor harus dilakukan jika target ingin terwujud.

Walaupun angka kasus TB di Samarinda merupakan jumlah kasus yang tertinggi di antara Kabupaten/Kota lainnya di Provinsi Kalimantan Timur, namun menurut beberapa responden dalam penelitian ini, temuan kasus TB di kota Samarinda masih jauh dibandingkan estimasi. Salah satu penyebabnya karena belum adanya payung hukum dalam program penanggulangan TB. Seperti diketahui, saat ini belum ada payung hukum untuk melakukan penanggulangan TB secara maksimal. Pembiayaan program TB yang beberapa tahun terakhir dilakukan oleh global fund di kota Samarinda telah berakhir sejak 2017. Maka sangat diperlukan perhatian bersama khususnya pemerintah daerah adalah ketika kerjasama dengan global fund terhenti. Dibutuhkan payung hukum berupa Peraturan Daerah (Perda) sehingga kemudian hari penanggulangan TB dapat lebih maksimal.

\section{KESIMPULAN}

Penelitian ini merupakan temuan-temuan baru di bidang penelitian mengenai kebijakan program $\mathrm{TB}$, tidak ditemukan adanya penelitian sebelumnya yang diketahui meneliti peraturan dan jenis kebijakan untuk program TB oleh para stakeholder. Berdasarkan hasil penelitian ini, kami merekomendasikan kasus TB harus lebih serius, persebarannya sangat cepat. Salah satunya untuk segera mengesahkan perda TB-HIV. 


\section{DAFTAR PUSTAKA}

Amo-Adjei, J., Kumi-Kyereme, A., Fosuah Amo, H., \& Awusabo-Asare, K. (2014). The politics of tuberculosis and HIV service integration in Ghana. Social Science and Medicine, 117, 42-49. http://doi.org/10.1016/j.socscimed.2014.07.008

Beauchamp, T.L., J. F. C. (2013). Principles of Biomedical Ethics. 7th ed. Oxford: Oxford University Press.

Damschroder, L.J., D.C. Aron, R.E. Keith, S.R. Kirsh, J. A. A., \& Lowery, and J. C. (2009). . Fostering Implementation of Health Services Research Findings into Practice: A Consolidated Framework for Advancing Implementation Science. Implementation Science 4:50.

Dholakia, R., Almeida, J., \& WHO Global Tuberculosis Programme. (1997). The potential economic benefits of the DOTS strategy against TB in India. TB Research. Retrieved from http://whqlibdoc.who.int/hq/1996/WHO_TB_96.218.pdf

Dinas Kesehatan Kota Samarinda. (2016). Profil kesehatan kota samarinda tahun 2016.

Dinas Kesehatan Provinsi Kalimantan Timur. (2016). 10 Penyakit Terbanyak Berdasarkan Pencatatan di Puskesmas Tahun 2016, 38.

European Commission. (2001). Green Paper: Promoting a European Framework for Corporate Social Responsibility. Brussels: European Commission.

Fuady, A., Houweling, T. A. J., Mansyur, M., \& Richardus, J. H. (2018). Catastrophic total costs in tuberculosis-affected households and their determinants since Indonesia's implementation of universal health coverage. Infectious Diseases of Poverty, 7(1), 1-14. http://doi.org/10.1186/s40249-017-0382-3

Gottret, P., \& Schieber, G. (2006). Health Financing Revisited. http://doi.org/10.1596/978-0-8213-6585-4

Health, M. and. (2001). 11622. Investing in Health for Economic Development. Report of the Commission on Macroeconomics and Health. Geneva: World Health Organization; 2001. p. 82-3., 12, 82-3. http://doi.org/10.1590/S1020-49892002000800018

Ireland, M., Paul, E., \& Dujardin, B. (2011). Can performance-based financing be used to reform health systems in developing countries? Bulletin of the World Health Organization, 89(9), 695-698. http://doi.org/10.2471/BLT.11.087379

Kemenkes RI. (2014). Pedoman TB nasional 2014.pdf.

Kemenkes RI. (2015). Rencana Aksi Nasional Kolaborasi TB-HIV 2015-2019. 
Rabin, B. A., Brownson, R. C., Haire-Joshu, D., Kreuter, M. W., \& Weaver, N. L. (2008). A glossary for dissemination and implementation research in health. Journal of Public Health Management and Practice, 14(2), 117-123. http://doi.org/10.1097/01.PHH.0000311888.06252.bb

Raviglione, M. C., \& Ditiu, L. (2013). Setting new targets in the fight against tuberculosis. Nature Medicine, 19(3), 263. http://doi.org/10.1038/nm.3129

Sheehy, B. (2017). Understanding CSR: An Empirical Study of Private Self-Regulation UNDERSTANDING CSR : AN EMPIRICAL STUDY OF PRIVATE REGULATION, (November 2012).

Sulis, G., Roggi, A., Matteelli, A., \& Raviglione, M. C. (2014). Tuberculosis: Epidemiology and control. Mediterranean Journal of Hematology and Infectious Diseases, 6(1). http://doi.org/10.4084/mjhid.2014.070

Uplekar, M., Weil, D., Lonnroth, K., Jaramillo, E., Lienhardt, C., Dias, H. M., ... Floyd, K. (2015). Viewpoint WHO' s new End TB Strategy. The Lancet, 6736(15), 1-3. http://doi.org/10.1016/S0140-6736(15)60570-0

Waagstein; Patricia Rinwigat. (2011). Themandatorycorporatesocialresponsibility in Indonesia:problemsandimplications.J.Bus.Ethics98(3),455-466.

WHO. (2016). WHO | Global tuberculosis report 2016. WHO 2016.

WHO for South East Asia. (2017). Bending The Curve Ending TB, Annual Report 2017. 